\title{
Chromosome 13
}

National Cancer Institute

\section{Source}

National Cancer Institute. Chromosome 13. NCI Thesaurus. Code C13208.

The designation for each member of the thirteenth largest human autosomal

chromosome pair. Chromosome 13 spans about 113 million base pairs and represents between 3.5 and $4 \%$ of the total DNA in normal diploid cells. 